\title{
Institutional Logics Behind the Corporate Social Responsibilities: A Study on Turkish Airline Companies*
}

\author{
Yeşim KURT iD a Senem BESLER iD b \\ a Kırklareli University, , Lüleburgaz Faculty of Aeronautics and Astronautics, Department of Civil Aviation Management, Kırklareli, \\ Turkey. yesimkurt@klu.edu.tr \\ b Anadolu University, Faculty of Economics and Administrative Sciences, Department of Business Administration, Eskişehir, Turkey. \\ sbesler@anadolu.edu.tr
}

\begin{tabular}{|c|c|}
\hline ARTICLE INFO & ABSTRACT \\
\hline $\begin{array}{l}\text { Institutional logics } \\
\text { Corporate social responsibility } \\
\text { New institutional theory }\end{array}$ & $\begin{array}{l}\text { Purpose - The subject of this study is the corporate social responsibilities of airline companies. The } \\
\text { study, it is aimed to reveal the reasons why airline companies carry out philanthropy corporate social } \\
\text { responsibility behaviors. In the research, institutional logic and new institutional theory literature are } \\
\text { used to achieve this goal. }\end{array}$ \\
\hline $\begin{array}{l}\text { Airline management } \\
\text { Air transportation management }\end{array}$ & $\begin{array}{l}\text { Design/methodology/approach - Qualitative research method is used in this research. The case study } \\
\text { method was used as a qualitative research design. The research area is formed by } 8 \text { airline companies } \\
\text { in Turkey. Semi-structured interviews and document analysis were used as a data collection method, } \\
\text { and all data were analyzed by the inductive method. }\end{array}$ \\
\hline $\begin{array}{l}\text { Received } 6 \text { April } 2021 \\
\text { Revised } 2 \text { November } 2021 \\
\text { Accepted } 12 \text { November } 2021\end{array}$ & $\begin{array}{l}\text { Findings - As a result of the analysis, two basic logic, community, and market, were found behind the } \\
\text { philanthropy responsibilities of airline companies. Although community logic has an impact on these } \\
\text { behaviors, market logic plays a dominant role. }\end{array}$ \\
\hline $\begin{array}{l}\text { Article Classification: } \\
\text { Research Article }\end{array}$ & $\begin{array}{l}\text { Discussion - Airline companies use philanthropy responsibilities for corporate and marketing } \\
\text { communications. These behaviors, which are seen as advertising and promotional activities, are carried } \\
\text { out with the pursuit of pragmatic legitimacy and to be preferred more by customers. According to the } \\
\text { results of the research, the concept of "philanthropy" functions as a myth that does not reflect the truth } \\
\text { and has a ceremonial meaning. }\end{array}$ \\
\hline
\end{tabular}

\section{INTRODUCTION}

Corporate social responsibility (CSR) has been emphasized by Bowen (1953) for the first time and has become the center of attention of different segments of society until today. Over time, this practice, which has been valued by academics, political authorities, non-governmental organizations (NGOs), and consumers, has also spread rapidly among commercial organizations (Campbell, 2007, p. 946). In the 1970s and 1980s, a paradigm shift occurred in the new world order with the effect of various changes such as globalization, liberalization, and technological developments, and a new approach towards businesses should behave responsibly (Green Paper, 2001, p. 4; Justice, 2002, p. 3). Liberalization efforts in air transportation in the 1970s have also developed air transportation, making it a transportation system used by the whole world. For this reason, aviation companies have also realized corporate social responsibility activities, which are a very popular practice today.

There are many studies in the literature that CSR activities have a positive impact on the financial performance of the organization in the long term. In addition to these advantages, CSR brings additional costs to the implementation process (McGuire et al., 1988, p. 854). Therefore, why airline organizations tend to implement CSR; The relationship between CSR practices and the effectiveness and efficiency of the organization emerges as an important research topic both academically and sectorally. The new institutional theory has dynamics and assumptions that can respond to these issues, which are useful for examining the reasons for the spread, adaption, and adoption of practices triggered by different actors in the organizational field. Most of the

* This research was produced from the doctoral thesis completed in Anadolu University, Institute of Social Sciences, Department of Civil Aviation Management in 2019. 
research that tries to make sense of CRS applications in the literature is based on new institutional theory and legitimacy assumptions (Aharonson and Bort, 2015; Khan et al., 2015; Beddewela and Fairbrass, 2016; Lynes and Andrachuk, 2008; Kuo et al., 2016; Killian, and O'Regan, 2016).

The subject of this study is the philanthropic responsibilities of airline companies. The purpose of the research is to explain the reasons why airline companies carry out philanthropic responsibility activities. To achieve this goal, the research uses new institutional theory and institutional logic. In this research, "What are the institutional logics behind the philanthropic corporate social responsibility of the airline companies in Turkey? an answer to the main research question is sought.

\section{CONCEPTUAL FRAMEWORK}

\subsection{Corporate Social Responsibility}

Bowen (1953) defines CSR as the improvement of society by making policies, making decisions, and implementing them following both the aims of the organizations and the expectations of the society. For this reason, social responsibilities are the obligation of organizations to take action on environmental and social problems (Orlitzky et. al., 2011, p. 3). Organizations continue their activities by considering not only their interests but also the interests of the society (Theaker, 2004, p. 183). Carroll sizes organizations' CSR practices from the bottom to the top, economic, legal, ethical, and philanthropic at four levels (Carroll, 1979, p. 499-500; 1991, p. 40-41). Accordingly, the primary responsibility of the organizations is the economic responsibilities associated with making a profit by meeting the needs and expectations of customers. The secondary responsibility of the organizations is related to the state acting following legal regulations. It is about thirdlevel ethical responsibilities in all activities and relationships of organizations concerning ethical norms that are valued by the society, even if they are not specified in the law, and adopting morally correct principles. Philanthropy is the top responsibility. According to Carroll, this dimension is about the behaviors that do not expect from organizations, they are not obliged to do, and if they do not, they will not face negative consequences such as any sanction or criticism by society. This dimension consists of all philanthropic activities initiated by the organization to contribute to society and the world it is in.

\subsection{The Paradox between Philanthropic and Obligation}

Although CSR is defined as a philanthropic concept that starts at the end of the law by many actors, it is emphasized that some are "must". It was not entirely voluntary for organizations to place more emphasis on corporate social responsibility. Many organizations have addressed these issues after encountering unexpected social reactions in matters that they did not see as part of their job responsibilities in the past (Güçdemir, 2006, p. 6). One of the important goals of organizations in carrying out CSR activities is the struggle to survive by organizing their relations with the environment of the organization (HetHof, 2009, p. 7). Social responsibility; It is imperative to make decisions under the values of the society by the owners and managers of the organizations, to evaluate the impact of their activities on the entire system, and to maintain a management policy accordingly (Davis, 1973, p. 312; Luthans and Hodgetts, 1972).

Globalization puts pressure on organizations to act more responsibly, making things faster, broader, and more visible than before (Blowfield and Murray 2014). Organizations' search for solutions to environmental issues, protests initiated by non-governmental organizations and carried in the media emerged due to environmental damages revealed by academic research. According to some researchers, organizations are concerned with environmental problems due to the pressures on them (Kramer and Porter, 2006, p. 5; Perez-Sanchez et al., 2003, p. 67).

CSR is seen as imperative to balance the organization's relations with its stakeholders. The demands of stakeholders to transfer resources from organizations to CSR applications are increasing (McWilliams and Siegel, 2001: 117; Sen and Bhattacharya 2001, p. 226). Today, consumers' expectations are not only to offer them the products and services they want at the price they want but also the organizations where they buy these products are useful corporate citizens of the society (Koçoğlu and Aksoy, 2017, p. 2).

For this reason, it is an important topic of discussion that the behaviors involving philanthropic in CSR practices are actually "for what reasons" and "how voluntarily". According to Pava and Krausz (1996, p. 322), even philanthropic activities are carried out to increase the value of the organization. The interest of these 
activities from the media and society is considered indirectly as advertising and serves the profit purposes of organizations (Brammer and Millington, 2005, p. 517).

\subsection{New Institutional Theory}

The new institutionalists argue that organizations do not only exist in the technical environment and emphasize the existence of the institutional environment. According to them, many organizational structures emerge as reflections of the institutional rules in this environment, in other words, institutionalized structures (Meyer and Rowan, 1977, p. 340). According to the theory, the official structures of the organization appear not as a result of the technical and administrative needs of production, but as reflections of rationalizing pressures or "myths" in the external environment (Bromley and Powell, 2012, p. 487). In other words, the theory suggests that organizations can gain legitimacy by following the practices in their institutional environment and by adopting the practices there (Suchman, 1995; Bromley and Powell, 2012, p. 487).

According to this theory, whether an organization is legitimate or not is determined by actors in the same organizational field that assesses its suitability to its environment (Ruef and Scott, 1998, p. 880). Organizations' compliance with the expectations of the actors in their institutional environment enables them to survive by facilitating their access to other resources, as well as being considered legitimate. Therefore, institutional rules in institutional environments function as "myths" that provide organizations with such advantages (Meyer and Rowan, 1977, p. 340; Zucker, 1987, p. 451).

There are various institutional pressures that direct organizations to such practices. Institutions consist of regulative, normative, and cultural-cognitive dimensions (Scott, 1995, p. 33; 2008, p. 222; Ruef and Scott, 1998, p. 878-879; Khan et al., 2015, 469-470). Adaptation to the pressures emerging in these dimensions legitimizes businesses. Legitimacy is seen as an organizational "imperative". According to the theory, there are three types of institutional legitimacy related to the actors' evaluations. These are pragmatic, moral, and cognitive legitimacy (Suchman, 1995, p. 572).

\subsection{Institutional Logics}

Institutional logics are concepts that have found themselves in the new institutional theory (Scales, 2014, p. 94), and have become a popular tool to explain the behavior of organizations by gaining clearer visibility in recent years (Cobb, et al., 2016, p. 2104; Scott, 1995). Institutional logic; offers a lens to examine the cause of different norms, goals, and practices and draws attention to the tensions and compromises on this issue (Vickers et al., 2017, p. 1757).

Institutional logics are used to explain how the behavior of actors reflects broader belief systems that construct ways of regulating reality (Friedland and Alford, 1991, p. 243; Nicolini et al., 2016, p. 229). These are associated with symbolic structures that provide frameworks of reference for the choice of individuals and organizations that make up society (Friedland and Alford, 1991, p. 248). Actors are exposed to a lot of logic due to institutionalized structures (e.g., family, religion, state). These logics enable actors to make decisions and take action by providing alternative information and schemes (Corbett et al., 2018, p. 263). In other words, institutional logic explains the organizational realities and explains how individuals or organizations make their decisions and what they use to protect their interests. For this reason, institutional logic is associated with powerful behavioral patterns that make sense and legitimate the behavior of organizations (Suchman 1995; Thornton 2002). They help organizations in their activities by creating organizational principles (Friedland and Alford, 1991).

Organizations must meet the demands of different stakeholders or actors. The new institutional theory proposes that these demands be conceptualized as institutional logic (Carlsson, et al., 2016, p. 47). The institutional logic mentioned here may cooperate and harmonize with each other, as well as compete or conflict (Friedland and Alford, 1991; Joseph et al., 2014, p. 1837). In other words, individuals or actors can be influenced by different institutional logic. Since the existence of multiple institutional logic causes different demands that need to be satisfied, it may create conflict or strengthen each other by dividing into departments and maybe in a facilitating relationship (Egels et al., 2015, p. 349; Xu et al., 2018). Organizational fields are organized by dominant institutional logics, although two or more institutional logics exist at the same time (Reay and Hinings, 2009, p. 629). 
Institutional logic is classified by various researchers from different fields. But its origin is based on the work of Friedland and Alford (1991). The basic logic put forward by Friedland and Alford (1991, p. 232), who have a voice in the emergence of logic, is the capitalist market, family, bureaucratic state, democracy, and religion. Freidson (2001) mentions three types of logic: market, bureaucracy, and professionalism. Nicolini et al. (2016) carried out their studies on pharmacy based on the classification of professional logic, market, corporate, and state logic. Jamali et al. (2017, p. 349) reveal the effects of state, market, corporation, family, profession, and religion, logic in their researches where they examine the dominant institutional logic behind CSR. Arena et al. (2018) reveal the effects of four logics, market, state, community, and profession, in their studies, where they investigate institutional logics that are effective on CSR activities. According to Glynn and Raffaelli (2013), organizations build their CSR activities on two logics: market and community. As a result of all these classifications, four basic logics emerge. The general characteristics of these logics are described in Table 1. below. The table was adapted from the work of various researchers in the literature to draw a clear framework for logic (Friedland and Alford, 1993; Miller, et al., 2017, p. 676; Wall, 2017, p. 393; Hesse et al., 2018; Arena et al., 2018; Freidson, 2001; Jamali et al., 2017; Reddy and Hamann, 2018; Brown et al., 2018).

Table 1. General Features of Institutional Logics

State It relates to the state's ownership, influence, and control over the activities. In other words, it is about the processes of monitoring, organizing, and transforming the state's institutional order. Words such as policy, law, regulation, minister, government, authority, executive, rule are frequently emphasized and activities are carried out within this framework. In other words, it is particularly concerned with regulatory institutional pressures. According to this logic, CSR activities are carried out for compliance with national and international regulations. In other words, state logic assumes, first of all, compliance with laws and regulations from regulatory agencies at different levels. For example, it is about this logic that an organization carries out environmental pollution measures due to compliance with regulations and therefore the preparation of sustainability reports. In another example, it relates to this logic that the organization carries out CSR activities on the subjects primarily promoted by the state. Collaborations or alliances are not necessary, even if they are carried out, joint work is carried out by government agencies.

Market It is about competition, the variety and quality of products or services. The market has power and is shaped by the preferences of the consumers who make up it. The most important thing is customer satisfaction and economic efficiency. It includes the organization's interests, profit maximization, competitive advantage, and performance-based behavior. Resources are used for this purpose and all activities are carried out for this purpose. In this logic, the choices are determined according to the expectations of the market. Collaborations and alliances during the activities are carried out for legitimacy and reputation. Transparency, corporate social reporting is seen as a tool for reputation management. According to this logic, CSR activities of the organizations are carried out primarily to meet customer expectations, to influence them, and to achieve economic results, than to fight against social or environmental difficulties.

Community It is about showing social sacrifice, thinking about the well-being of society, and monitoring and improving social problems. It emphasizes the contribution of an organization to the communities with which it interacts. The organization's desire to provide social benefit is more important than its economic gains. No distinction is made between social responsibilities for different stakeholders. The important thing is to support in pure good faith. Cooperation and alliances are carried out by actors that are part of the community, such as local communities, associations, non-governmental organizations, and reporting is also done for the satisfaction of the community.

Profession It is related to an order in which people with expert knowledge control the activities. Colleagues oversee each other's activities. Accreditation standards are determined and implemented through professional organizations or associations. Individuals or 
organizations use their professionalism to make decisions on behalf of others and are dedicated to helping others. It concerns ethical behavior and activities are shaped by the desire to provide high-quality professional services for the benefit of others. Cooperation and alliances are carried out by actors connected to the professional network. Special training, career advances are important with activities aimed at developing expertise. It concerns professional specialties based on peer surveillance. He argues that there is no priority among environmental, social, and economic objectives. Whatever is done, the important thing is to do it as recommended by the experts. It concerns normative institutional pressures related to CSR activities. For example, GRI or AA1000 standards serve the professional logic in CSR activities and form the basis of reporting.

\section{METHOD}

This research was carried out by the qualitative research method. The case study method was used as a qualitative research design. The data collection method used in the research, the research area and participants, and information on data analysis are explained below.

\subsection{Data Collection Method}

Semi-structured interviews and document analysis were used as a data collection method. Before the semistructured interviews, a pilot study was planned to review the research method and interview questions (Glesne, 2013, p. 74). Details about this study are shown in Table 2.

Table 2. Pilot Study

\begin{tabular}{rllll}
\hline Code Name & Title & Date & Hour & DURATION \\
\hline P1 & Corporate communications manager & 26.05 .2018 & $14: 00$ & $50 \mathrm{~min}$. \\
\hline
\end{tabular}

Also in the research, all documents related to corporate social responsibility from the airline organizations' websites are the secondary data source (Glesne, 2013, p. 118; Creswell, 2013, p. 190). NVivo12 program was obtained through NCapture and included in the analysis process.

In qualitative research, it is trying to explain the events or cases by interviewing the expert participants who are chosen by purposeful sampling and who can represent the scope of the research in the best way (Berg, 2001 p. 32; Patton, 2002, p. 243). For this reason, by selecting the purposeful sampling method in this research, experts were interviewed about decision-making and implementing corporate social responsibility practices in the airline organizations that make up the research area. Since one of the 8 airline companies in the research area did not respond to the interview, a total of 8 managers from 7 other airlines were interviewed. Details of the relevant interviews are shown in Table 3).

Table 3. Semi-Structured Interview Data Collecting Table

\begin{tabular}{lllll}
\hline Code Name & Date & Time & Duration & Data Collecting Mode \\
\hline P1 & 01.08 .2018 & $14: 00$ & $52: 33 \mathrm{~min}$. & Interview and voice recording \\
\hline P2 & 06.08 .2018 & $16: 00$ & $29: 16 \mathrm{~min}$. & Interview and voice recording \\
\hline P3 & 07.08 .2018 & $14: 00$ & $1: 00: 35 \mathrm{~min}$. & Interview and voice recording \\
\hline P4 & $09: 08.2018$ & $10: 00$ & $47: 45 \mathrm{~min}$ & Interview and voice recording \\
\hline P5 & 10.08 .2018 & $10: 00$ & $47: 50 \mathrm{~min}$. & Interview and voice recording \\
\hline P6 & 13.11 .2018 & $16: 00$ & $31: 44 \mathrm{~min}$ & Interview and voice recording \\
\hline P7 & 14.11 .2018 & $15: 00$ & $33: 46 \mathrm{~min}$ & Interview and voice recording \\
\hline
\end{tabular}

\subsection{Research Area and Participants}

The area of this research is the airline organizations engaged in passenger transport in Turkey. These organizations are listed below:

- Turkish Airlines

- Pegasus Airlines 
- Onur Air

- Atlasjet Airlines

- SunExpress

- Freebird Airlines

- Corendon Airlines

- Tailwind Airlines

The details of the experts who participated in the semi-structured interviews from the relevant airlines by purposive sampling method are shown in Table 4:

Table 4. Participants' Work Experience

\begin{tabular}{lll}
\hline Number & The Titles of the Participants & $\begin{array}{l}\text { Duration } \\
\text { Experience }\end{array}$ \\
\hline $\mathbf{1}$ & Corporate communication manager & 5 years \\
\hline $\mathbf{2}$ & Corporate communication and public relations manager & 9 years \\
\hline $\mathbf{3}$ & Senior corporate communication and sponsor relations specialist & 6 years \\
\hline $\mathbf{5}$ & Head of corporate communications & 2 years \\
\hline $\mathbf{6}$ & Brand communication manager & 2,5 years \\
\hline 7 & Corporate communication manager & 9 years \\
\hline 8 & Agreements and marketing manager & 10 years \\
\hline
\end{tabular}

\subsection{Data Analysis Method}

During the analysis, the methods of preparing and editing the data for analysis, reading the whole data, coding the data, and reaching the themes and descriptions were followed. In other words, the data were analyzed by the inductive method (Creswell, 2008, p. 185).

\section{FINDINGS AND INTERPRETATION}

As a result of the analysis of documents and interview data, it was determined that 6 of the 8 airline companies that make up the research area performed philanthropic CSR practices. These philanthropic activities have emerged in different categories. These are to support health; giving support to children; commemorations and celebration of religious and national holidays; supporting education and training; providing dressing, feeding, and sheltering assistance to those in need; supporting civil society organizations; support for transportation and environmental responsibilities. The following expressions encountered in the documents of airline companies are examples of these:

"As Turkish Airlines, we organized a health camp where approximately 1,000 patients underwent cataract surgery in cooperation with a local hospital affiliated to the Ethiopian Ministry of Health. We aim to realize this project in other African countries."

"As an extension of environmental policy, Corendon Airline's plant seedlings on behalf of its guests who have a holiday with Corendon in cooperation with Tema Foundation. Corendon Airlines is conducting a social responsibility project by establishing forest monuments in various cities in Turkey. "

When the discourses of organizations about the institutional logic behind these activities are analyzed, two basic logics, one of which is the dominant institutional logic, are encountered. The first is the community, and the second is the dominant institutional logic, the market. Even if there are two or more institutional logics at the same time in organizational fields, it is expected that these fields will be managed by a dominant institutional logic (Reay and Hinings, 2009, p. 629).

\subsection{Community Logic}

The primary logic of organizations in the research field to carry out these activities is the market logic, which will be discussed in the next category. Also, it is seen that activities aimed at improving society and the world are inspired by the logic of society. P2 says this logic, "If there is a contribution we can make based on such a social need, we will take an attitude about it anyway." This supports the words. 
P4 made the following explanation that nurtures this logic of its airline organization;

"Soma, you know, was an accident. After one year and two years, we took these children and took them to Frankfurt, and we had 3 days they could not forget. Did those children go abroad before, did not go ... We took those children there, they had a wonderful three days. After that, when we see the change in the behavior of their eyes on that face, we say that we have done this job well."

\subsection{Market Logic}

The main reason behind CSR implementations explains the market logic emerging as the dominant institutional logic. It has been determined that the vast majority of CSR activities related to the philanthropic aspect of airlines are carried out more intensely than the logic of the community, with the market logic. Under this theme, two categories have emerged, the use of CSR in corporate communication and marketing communication.

\subsubsection{The category of using CSR in corporate communication}

It consists of the sub-categories of airline organizations to carry out CSR activities in areas that will strengthen the brand and gain a corporate reputation as a priority.

According to the sub-category of performing CSR activities in areas that will strengthen the brand, airline organizations make choices that are suitable for their brands while conducting CSR activities and perform CSR to further strengthen their brands. This is stated in the case P2 as follows:

"The company's business and communication goals are very important. Social responsibility may be done voluntarily when it is done individually, but when done by the institution, it should be working consistently with the company's communication goals. Therefore, we prefer to do social responsibility studies in areas where we want us to be strong in our brand perception, in some places we want to be strong in our brand perception, rather than just having a social responsibility work in one place."

According to the participants, as brand awareness increases due to CSR activities, customers' ticket preferences are also positively affected. The benefits of creating a "brand that performs corporate social responsibility activities" perception are explained by various participants in the research as follows:

P3: "Once you show that you are a sensitive brand. Therefore, this increases your preferability...... The more you support, the more you contribute to society, the easier it is to be preferred as a brand. Now, social responsibility projects of brands and their contribution to society are of great importance in the brand choices of many consumers. If a brand in one sector supports one area and the other does not, you choose the product of the brand that gives support as a consumer... I think everyone is doing it for the same reasons. To increase the corporate reputation and demonstrate its reliability in that field."

According to the sub-category of the importance of gaining reputation, organizations in the field of research believe that carrying out CSR activities contributes to making their names known in the media and thereby managing their reputation and using CSRs for these purposes. P5 and P7 clarify this situation as follows:

P5: "Commercial organizations always want to take part in the media in their work... That's why all companies use social responsibility projects in the media, frankly. I do not see anything wrong with this, it is both satisfied, their names are mentioned, reputation management is done and social responsibility projects are realized. "

P7: "My opinion is that when they do something good, they also do something good for themselves. In other words, if I contribute to society, I contribute to the environment, I contribute in any way, and I get the opportunity to announce it in myself. I announce my name beautifully in this way, I am doing a good project. Therefore, one of the most important effects is reputation."

In the research, the findings indicating that CSR strengthens the image of the organization, in other words, the codes that feed this sub-category were also reached. The impact of CSR on the image of the organization is P3, "The contribution to your business is already an image ... the more the companies support the society, the more they can accommodate and their images increase." While summarizing the words, P8 makes the following explanations:

"So, after all, the biggest promotion thing today is to touch the emotions of people. In other words, when we look at the activities and advertisements that have succeeded, if there is something that appeals to the emotion of the people 
in the sectoral sense, it has been successful. So, in this sense, if social responsibility achieves such a thing, it is necessarily recycling. In other words, there is a commercial return, and a return in the sense of the brand image."

\subsubsection{The category of using CSR in marketing communication}

The second category that reveals market logic is that airline organizations use CSR activities in marketing communication. It is the codes that refer to this category as CSR activities are carried out according to the expectations of the target audience or the market rather than the whole society, that CSR is considered as an indirect marketing tool, that CSR activities are carried out to expand their markets, and that CSR is evaluated as an advertisement and promotional activity. The following participant views explain this category:

P4: "Social responsibility is an issue that can be addressed in many ways. But the popular part of the real business is the environment, forest, investment in children. Why do I say these are popular because they are really what touches everyone on the street. All institutions also subtract the PR value from them. In other words, by turning this into news, creating a positive perception of the people that that institution fulfills its duty by undertaking certain responsibilities in terms of social responsibility in this sense. Now, we try to make PR for our responsibilities as an institution. Ultimately, a return must be provided. The emotional satisfaction of the work is spiritual satisfaction, but we have another truth, it must have a return. That's why we try to do this in cooperation with the media."

P6: "Now, recognition is very important here. When people return an ad, they can say that this ad is. But social responsibility projects that directly address the emotion that appeals to the heart can be kept in mind more in people. Unfortunately, my overall observation is part of the advertisement for social responsibility. When we look at all the companies that do this, this is a share of their advertising budget. So it's not a socially responsible budget. In other words, there is no budget-related to social responsibility budget in its balance sheet."

P8: "In a social responsibility project, you do not have much chance to show yourself as you are. You have to show yourself very well... I think it's not ethical because people's marketing and sales strategies must go over people's minds. I think that any marketing technique that tries to pass through the hearts of people is not ethical."

One of the important proofs that CSR is realized with the logic of the market is the explanations of the participants from 2 out of 8 organizations in the research area. These two organizations carry out charter flights. In other words, it applies with a strategy that does not directly sell to the customer, therefore does not need advertising and promotional activities. These airline organizations state that, due to their strategies, they do not need positive effects on the market that will be brought by corporate social responsibility, therefore they do not perform social responsibility. Two participants clarify this situation as follows:

"You know social responsibility, this country is seen as a branch of marketing and advertising activities. In this sense, we are a charter airline company since we do not have a goal to reach a direct passenger or sell tickets. In this sense, we have not participated in such a project so far."

"When we look at something we consider social responsibility projects as part of public relations activities. Especially since our airline is a charter airline, it is not a company that includes customer-oriented direct advertising and promotional activities. Why this is. We don't have a direct ticket sale, so we don't need advertising."

\subsection{The Relationship between Institutional Logic, Actors, Pressures, Legitimacy, and Isomorphism}

Although the activities carried out by organizations to improve society seem to be related to philanthropy, the participants made the opposite statements. According to them, CSR is carried out to increase the brand value and image of their organizations, to manage their reputation, to use CSR as an advertisement and promotional activity, and in this way to reach more customers and to sell more tickets. According to the participants, there is pressure coming from society and the customers, although there is no legal sanction against philanthropic CSR. Organizations carrying out such activities are preferred more by being seen as more legitimate in society and the eyes of customers and contribute to their sustainability as they are preferred. Therefore, an invisible dependency emerges between CSR and the sustainability of the organization. Organizations have to carry out philanthropic CSR activities to manage these dependencies. Activities that are not mandatory by law, which will not be carried out under normal conditions, but carried out by feeling dependent and compulsory, indicate regulatory institution (Scott, 1995, p. 33). These pressures play a role as a carrier mechanism, leading to the spread of CSR activities among organizations. The following statement of P8 supports this situation, 
which from the outside looks like corporate social responsibility, but expresses other understandings for the organization:

"Not everyone sees the big picture all the time. Let me know that you are trying to fly to X city and you want to establish good relations with the $X$ mayor. For the mayor of $X$ to support your flights there, you have to make a small monument to the river there. You make this monument, I think this is not a social responsibility project. The public can see it that way, but you are trying to regulate the relations with the mayor... I mean, I can fly to X or if I have a problem with the Mayor of X, I may be doing it to organize relations with him. I have no problem with the mayor of $X$, but if there is a reaction by the people of $X, I$ can do it to influence the people of $X$. "

P5 summarizes the pressure they feel as follows:

"People are very conscious. People are asking for an account. So now they are back and asking what you are doing for the environment. In this regard, we are trying to renew our fleet with environmentally friendly planes... We also try to give our new orders from environmentally friendly planes as much as possible... European passengers are very conscious. So they consider this in their elections. They ask companies for an account."

Regarding market logic, there is a search for pragmatic legitimacy in the direction of airline companies towards these practices. Because businesses carry out such activities by looking to be legitimate in the eyes of actors such as society, customers, media, and non-governmental organizations and considering their rational interests (Suchman, 1995). P4 and P5 express this situation with the following words:

P4: "Media is one of the most important parts of this business. Your work needs to be explained to people. We are talking about doing the PR of the work done. This is not just a matter of helping children. We are also working in an institution, this institution is a commercial company, you have to explain that this commercial company has every return of money spent. The media also plays a very important role here. Now, if the media is not more encouraging and supportive of these issues, then which institution will do this? Yes, we live a spiritual pleasure by helping, and we are happy when we see this joy. It is an indisputable fact, but it is worth repeating. We are a commercial business. Any action that a commercial business makes should ultimately benefit from it. We have to say that this company bought something like this, recycling has achieved a benefit. If we do not say, 'I am not a non-governmental organization' will say the top man."

P5: "Commercial organizations always want to be in the media in their works...Be a sponsor, your logo is not displayed, your name is not read, it is getting harder even in the newspaper. But whenever it comes out with a social responsibility project, a company gets much more, it gets a place in the press. Therefore, all companies use social responsibility projects in the media to take part, frankly... It is now seen within the scope of their marketing efforts. This is inherent in the work. Commercial firms have to take care of this. "

Also, according to the findings of the research, it has been determined that there is no isomorphism among the philanthropic social responsibility activities carried out by the organizations in search of pragmatic legitimacy. The main reason for this can be associated with market logic. These organizations, acting with their rational interests, use these practices to manage their reputation, image, brand perception, as explained in the section where the market logic is discussed. Accordingly, organizations think that it will be beneficial to perform applications that will make a difference, not to perform similar applications to others, and prefer to stay away from emulation. The signs of this finding reveal the following words:

P1: "As a brand, I have to say this. Usually, we try not to do duplicate works, which I would not want our brand to be perceived as follows: "The same Turkish Airlines did, the X company did too." That's why we always try to do something different from our competitors. That's the important thing."

When all these findings are evaluated together, the concept of philanthropic functions as a myth that does not reflect the truth serves rational interests and is used with the pragmatic legitimacy tool. P8 makes the following explanation that performing CSR is to manage customer preferences and that the concept of philanthropy is a myth. Pure community logic is ignored with this explanation:

"So you are a commercial enterprise... commercial enterprise is profit-oriented. Why would a commercial enterprise help somewhere else? Does it make any sense? All commercial enterprises do their social responsibility projects to earn money. They do it to manage perception. They do it to look good. They do it for better perception. One day, when 
that person needs to buy a product, they stay in mind to prepare the sub-floor and psychological basis of choosing their products. There is no other reason."

\section{CONCLUSION AND DISCUSSION}

In this study, philanthropic responsibility activities perpetrated by the Airline business in Turkey have tried to explain the new institutional theory and institutional logic. The results of the research are summarized in Table 5:

Table 5. Institutional Lens of Corporate Social Responsibilities

\begin{tabular}{ll}
\hline Institutional Logics & Market (dominant)+ Community \\
\hline Institutional dimension & Regulatory. Feeling compulsory to be preferred by the customer and society. \\
\hline Institutional actor & Society, customers, media, non-governmental organizations. \\
\hline Institutional legitimacy & Pragmatic. \\
\hline Institutional isomorphism & None. Reasons for adoption are common, adaptation methods are different. \\
\hline
\end{tabular}

In the research, it was determined that two different institutional logics were effective in philanthropic responsibilities. One of them is the community and the other is market logic. According to the results of the research, the main reason behind the philanthropic CSR activities of airline companies is the dominant market logic and pragmatic legitimacy concerns are at the forefront. This result shows the results in parallel with the study conducted in a different sector in the literature (Glynn and Raffaelli, 2013). Besides, organizations' use of these practices as a competitive tool and acting with market logic caused the CSR activities to be different from others. Therefore, no uniformity has been observed between these applications.

Accordingly, "philanthropic" in the CSR activities of the airlines that make up the field of research emerges as a myth that does not reflect the truth in terms of meaning and is not done with pure goodwill such as improving the society. The reasons for organizations to focus on these activities are related to cost-benefit analysis and rational interests, and organizations carry out CSR activities to achieve these interests. For this reason, while the concept of "philanthropic" as a discourse visibly makes sense and is adopted ceremonially; the practice itself refers to a rational choice for organizations and is rationally adopted. This result overlaps with some studies that question how philanthropic CSR practices are performed. The results of the research support some studies in the literature, which state that voluntary activities occur as a result of necessity. In related studies, it is stated that due to the conflicting nature of the organization, social responsibility activities are not carried out with pure kindness and philanthropy, these activities are put forward to avoid sanctions from the society and the concept of socially responsible organization is an impossibility (Brammer et al., 2012; Kuo et al., 2016).

This research highlights the paradox between philanthropy and obligation is limited to the airline organizations in Turkey. Conducting similar research on different types of aviation organizations and in different sectors, both nationally and internationally, will contribute to a better understanding of corporate social responsibility and the concept of philanthropy.

\section{REFERENCES}

Aharonson, B. S., and Bort, S. (2015). Institutional pressure and an organization's strategic response incorporate social action engagement: the role of ownership and media attention. Strategic Organization, 13(4), 307-339.

Arena, M., Azzone, G., ve Mapelli, F. (2018). What drives the evolution of Corporate Social Responsibility strategies? An institutional logic perspective. Journal of Cleaner Production, 171, 345-355.

Beddewela, E., and Fairbrass, J. (2016). Seeking legitimacy through CSR: Institutional pressures and corporate responses of multinationals in Sri Lanka. Journal Of Business Ethics, 136(3), 503-522.

Berg, B. (2001). Qualitative research methods for the social science (4. Bask1). USA: A Pearson Education Company.

Blowfield, M., and Murray, A. (2014). Corporate responsibility. Oxford University Press. 
Bowen, H. R. (1953). Social responsibilities of the businessman. New York: Harper And Row

Brammer, S., Jackson, G., and Matten, D. (2012). Corporate social responsibility and institutional theory: New perspectives on private governance. Socio-Economic Review, 10(1), 3-28.

Brammer, S., and Millington, A. (2005). Profit maximisation vs. agency: An analysis of charitable giving By Uk Firms. Cambridge Journal Of Economics, 29(4), 517-534.

Bromley, P., and Powell, W. W. (2012). From smoke and mirrors to walking the talk: Decoupling in the contemporary world. Academy of Management Annals, 6(1), 483-530

Brown, J. A., Clark, C., and Buono, A. F. (2018). The United Nations global compact: Engaging implicit and explicit CSR for global governance. Journal of Business Ethics, 147(4), 721-734.

Campbell, J. L. (2007). Why would corporations behave in socially responsible ways? An institutional theory of corporate social responsibility. Academy Of Management Review, 32(3), 946-967.

Carlsson-Wall, M., Kraus, K., and Messner, M. (2016). Performance measurement systems and the enactment of different institutional logics: insights from a football organization. Management Accounting Research, $32,45-61$.

Carroll, A. B. (1979); A Three-dimensional conceptual model of corporate performance; Academy of Management Review, Vol. 4, No.4; P: 497-505 DOI: 10.2307/257850

Carroll, A. B. (1991); The Pyramid Of Corporate Social Responsibility: Toward The Moral Management Of Organizational Stakeholders, Business Horizons; Julyaugust; P: 39-48

Carroll, A. B. (1999). "Corporate social responsibility: evolution of a definitional construct." Business and Society, 38 (3): 268-95. https://doi.org/10.1016/0007-6813(91)90005-G

Cobb, J. A., Wry, T., and Zhao, E. Y. (2016). Funding financial inclusion: Institutional logics and the contextual contingency of funding for microfinance organizations. Academy of Management Journal, 59(6), 21032131.

Corbett, J., Webster, J., and Jenkin, T. A. (2018). Unmasking corporate sustainability at the project level: Exploring the influence of institutional logics and individual agency. Journal of Business Ethics, 147(2), 261-286

Creswell, J. W. (2008). Research Design: Qualitative, quantitative, and mixed methods approach (3. Bask1.). Sage Publication

Creswell, J. W. (2013). Araştırma deseni: nitel, nicel ve karma yöntem yaklaşımları. (Çev: S. B. Demir.) Ankara: Eğiten Kitap

Davis, K. (1973). The case for and against business assumption of social responsibilities. Academy of Management Journal, 16(2), 312-322. https://doi.org/10.5465/255331

Egels-Zandén, N., Lindberg, K., and Hyllman, P. (2015). Multiple institutional logics in union-NGO relations: private labor regulation in the Swedish Clean Clothes Campaign. Business Ethics: A European Review, 24(4), 347-360.

Fincham, R., and Forbes, T. (2015). Three's a crowd: The role of inter-logic relationships in highly complex institutional fields. British Journal of Management, 26(4), 657-670.

Freidson, E. (2001). Professionalism, the third logic: On the practice of knowledge. University of Chicago Press.

Friedland, R. (2012) God, Love and Other Good Reasons for Practice: Thinking Through Institutional Logics

Friedland, R., and Alford, R. R. (1991). Bringing society back in: Symbols, practices and institutional contradictions.

Friedman, M. (1970). The social responsibility of business is to increase its profits. New York Times Magazine, September, 13.

Glesne, C. (2013). Nitel Araştırmaya Giriş (3 Baskı). (Çev: A. Ersoy and P. Yalçınoğlu) Ankara: Anı Yayıncılık. 
Glynn, M. A., and Raffaelli, R. (2013). Logic pluralism, organizational design, and practice adoption: The structural embeddedness of CSR programs. In Institutional Logics in Action, Part B (pp. 175-197). Emerald Group Publishing Limited.

Green Paper, (2001). Promoting European framework for corporate social responsibility, European Commission,

Güçdemir, Y. (2006). Bankaların web sitelerinin sosyal sorumluluk açısından incelenmesi. İstanbul Üniversitesi Iletişim Fakültesi Hakemli Dergisil İstanbul University Faculty of Communication Journal, (26).

Hesse, A., Kreutzer, K., and Diehl, M. R. (2018). Dynamics of Institutional Logics in a Cross-Sector Social Partnership: The Case of Refugee Integration in Germany. Journal of Business Ethics, 1-26.

Hethof, S. D. (2009). Türkiye'de kurumsal sosyal sorumluluk üçgeni: Şirketler, toplum ve toplum kuruluşları. TÜBITAK Project.

Jamali, D., Karam, C., Yin, J., and Soundararajan, V. (2017). CSR logics in developing countries: Translation, adaptation, and stalled development. Journal of World Business, 52(3), 343-359. https://doi.org/10.1016/i.jwb.2017.02.001

Joseph, J., Ocasio, W., and McDonnell, M. H. (2014). The structural elaboration of board independence: Executive power, institutional logics, and the adoption of CEO-only board structures in US corporate governance. Academy of Management Journal, 57(6), 1834-1858.

Justice, D. W. (2002). Corporate social responsibility: Challenges and opportunities for trade unionists. https://digitalcommons.ilr.cornell.edu/codes/9

Khan, Z., Lew, Y. K., and Park, B. I. (2015). Institutional legitimacy and norms-based CSR marketing practices: insights from MNCs operating in a developing economy. International Marketing Review, 32(5), 463491.

Killian, S., \& O'Regan, P. (2016). Social accounting and the co-creation of corporate legitimacy. Accounting, Organizations and Society, 50, 1-12.

Koçoglu, C. M., and Aksoy, R. (2017). demografık degıskenlerın kurumsal sosyal sorumluluk algısı üzerındekı etkılerıne yönelık bır arastırma*/A study to the impact of demographıc variables on the perception of corporate social responsibility. International Journal Of Management Economics and Business, 13(1), 89.

Kramer, M. R., and Porter, M. E. (2006). Strategy and Society: The link between competitive advantage and corporate social responsibility. Harvard Business Review, 84(12), 78-92.

Kuo, T. C., Kremer, G. E. O., Phuong, N. T., and Hsu, C. W. (2016). Motivations and barriers for corporate social responsibility reporting: Evidence from the airline industry. Journal Of Air Transport Management, 57, 184-195.

Luthans, F., and Hodgetts, R. M. (1972). Social issues in business.

Lynes, J. K., and Andrachuk, M. (2008). Motivations for corporate social and environmental responsibility: A case study of Scandinavian Airlines. Journal of International Management, 14(4), 377-390.

McGuire, J.B., Sundgren, A. and Schneeweis, T., (1988). Corporate and social responsibility and firm financial performance. Acad. Manag. J. 31, 854-872.

Mcwilliams, A., and Siegel, D. (2001). Corporate social responsibility: A theory of the firm perspective. Academy Of Management Review, 26(1), 117-127.

Meyer, J. W .and Rowan, B. (1977). Institutionalized organizations: Formal structure as myth and ceremony. American Journal of Sociology,340-363 http://www.jstor.org/stable/2778293

Miller, D., Le Breton-Miller, I., Amore, M. D., Minichilli, A., and Corbetta, G. (2017). Institutional logics, family firm governance, and performance. Journal of Business Venturing, 32(6), 674-693.

Nicolini, D., Delmestri, G., Goodrick, E., Reay, T., Lindberg, K., and Adolfsson, P. (2016). Look what's back! Institutional complexity, reversibility, and the knotting of logics. British Journal of Management, 27(2), $228-248$ 
Orlitzky, M., Siegel, D. S., \& Waldman, D. A. (2011). Strategic corporate social responsibility and environmental sustainability. Business \& Society, 50(1), 6-27.

Patton, M. (2002). Qualitative research and evaluation methods. California: Sage Publication.

Pava, M. L., and Krausz, J. (1996). The association between corporate social responsibility and financial performance: The paradox of social cost. Journal Of Business Ethics, 15(3), 321-357.

Perez-Sanchez, D., Barton, J. R., and Bower, D. (2003). Implementing environmental management in SMEs. Corporate Social Responsibility and Environmental Management, 10(2), 67-77.

Reay, T., and Hinings, C. R. (2009). Managing the rivalry of competing institutional logics. Organization studies, 30(6), 629-652.

Reddy, C. D., and Hamann, R. (2016). Distance makes the (committed) heart grow colder: MNEs' responses to the state logic in African variants of CSR. Business and Society, 0007650316629127.

Ruef, M., and Scott, W. R. (1998). A multidimensional model of organizational legitimacy: Hospital survival in changing institutional environments. Administrative science quarterly, 877-904.

Scales, K. (2014). Doing what makes sense: Locating knowledge about person-centred care in the everyday logics of longterm care (Doctoral dissertation, University of Nottingham).

Scott, W. R. (1995). Introduction: Institutional theory and organizations. The Institutional Construction Of Organizations. ( Ed: S. Christensen and W. R. Scott). Thousand Oaks: Sage.

Scott, W. R. (2005). Institutional theory: Contributing to a theoretical research program. Great minds in management: The process of theory development, 37, 460-484.

Scott, W. R. (2008). Lords of the dance: Professionals as institutional agents. Organization studies, 29(2), 219-238.

Sen, S., and Bhattacharya, C. B. (2001). Does doing good always lead to doing better? Consumer reactions to corporate social responsibility. Journal of Marketing Research, 38(2), 225-243.

Suchman, M. C. (1995). Managing Legitimacy: Strategic and institutional approaches. Academy Of Management Review, 20(3), 571-610. http://www.jstor.org/stable/258788

Thornton, P. H. (2002). The rise of the corporation in a craft industry: Conflict and conformity in institutional logics. Academy of management journal, 45(1), 81-101. DOI: 10.2307/3069286 https://www.jstor.org/stable/3069286

Vickers, I., Lyon, F., Sepulveda, L., and McMullin, C. (2017). Public service innovation and multiple institutional logics: The case of hybrid social enterprise providers of health and wellbeing. Research Policy, 46(10), 1755-1768.

Wall, L. (2017). Institutional logics and curriculum decision making: enacting the Australian Curriculum English and NAPLAN literacy. The Australian Educational Researcher, 44(4-5), 391-407.

Xu, D., Chen, C., and Wu, X. (2018). Ownership structure and the use of non-family executives in familydominated Chinese listed firms: An institutional logics perspective. Asia Pacific Journal of Management, $1-24$.

Zucker, L. G. (1987). Institutional theories of organization. Annual review of sociology, 13(1), 443-464. 